\title{
Effect of Microsporidian Parasite Enterocytozoon hepatopenaei (EHP)on Pond Profitability in Farmed Pacific White Leg Shrimp Litopenaeus vannamei
}

\author{
M. Raveendra ${ }^{*}$, G. Suresh ${ }^{2}$, E. Nehru ${ }^{3}$, D. Pamanna ${ }^{2}$, D. Venkatesh ${ }^{2}$, M. Yugandhar \\ Kumar $^{1}$, A.S. Sahul Hameed ${ }^{4}$, Ch. Srilatha ${ }^{5}$, P. Hari Babu ${ }^{2}$ and T. Neeraja ${ }^{2}$ \\ ${ }^{1}$ Krishi Vigyan Kendra, Lam, Guntur, Sri Venkateswara Veterinary University, Tirupati, \\ Andhra Pradesh, India \\ ${ }^{2}$ College of Fishery Science, Muthukur, Nellore, Sri Venkateswara Veterinary University, \\ Tirupati, Andhra Pradesh, India \\ ${ }^{3}$ Fisheries field officer, Telangana, India \\ ${ }^{4}$ OIE Reference Laboratory for WTD, Department of Zoology, C. Abdul Hakeem College, \\ Melvisharam, Tamil Nadu, India \\ ${ }^{5}$ College of Veterinary Science, Sri Venkateswara Veterinary University, Tirupati, \\ Andhra Pradesh, India \\ *Corresponding author
}

\begin{tabular}{|l|}
\hline Ke y w o r d s \\
EHP, HPM, \\
Microsporidian \\
Parasite, PCR, \\
Shrimp, WFS \\
\hline Article Info \\
\hline $\begin{array}{l}\text { Accepted: } \\
\text { 12 April } 2018 \\
\text { Available Online: } \\
\text { 10 May 2018 }\end{array}$ \\
\hline
\end{tabular}

A B S T R A C T

In recent years, a number of diseases have been negatively effecting on shrimp aquaculture. More recently, Enterocytozoon hepatopenaei (EHP), a microsporidian parasite causes Hepatopancreatic Microsporidiosis (HPM) to be associated with white feces syndrome (WFS) and slow (retarded or stunted) growth in farmed L. vannamei (pacific white leg shrimp) in many of the shrimp growing countries in Asia, also in India. Numerous studies revealed that the pathogen causing significant economic losses to the shrimp industry. So, to evaluate the economical importance of this parasite on pond profitability, five (5) farm pond production effected by both EHP and white feces syndrome were compared with five (5) normally performed shrimp population with biosecured environment by adopting best management practices (BMPs). Important diagnoses observed were histopathological studies and molecular technique (PCR). Histologically, EHP infected animals showed severe degeneration of hepaotopancreatic tubule, basophilic inclusions resembling the developmental stages of EHP were found in the epithelial cells and large number of spore aggregations was observed in the tubular lumen. EHP infected ponds have poor performance in average daily growth (ADG), days of culture (DOC), average body weight (ABW), feed conversion ratio (FCR) and shrimp biomass compared to normal healthy ponds. The shrimp population in EHP infected ponds having white feces syndrome (WFS) showed FCR of over 2.92 to 3.17 (can be considered as 3.0) where as normal growth ponds showed FCR of 1.83 to 1.94 (can be considered as 1.9). The portal route of entry of pathogen into shrimp was evaluated by performing oral feed bioassay, it was revealed that EHP can be transmitted through per os feeding of EHP infected hepatopancreas tissue to healthy shrimp. This is the first report to evaluate the economic importance of EHP on pond profitability. 


\section{Introduction}

Aquaculture has been an important sector in the introduction, transfer and spread of aquatic diseases in the fisheries. The introduction of exotic pathogens along with newly introduced aquatic animals has too often resulted in severe socio-economic and ecological impacts (Klinger and Floyd, 2002).

Diseases of viral etiology are of more significance and have led to huge economic losses in all shrimp farming regions of the world (Kiran and Shyam, 2012). There are about 20 viral diseases reported from shrimps and the average annual economic losses are in the tune of 1.0 billion US\$ (Kiran and Shyam, 2012). Nine viruses are responsible for main considerable economic losses. These include White Spot Virus (WSV), Infectious Hypodermal and Hematopoietic Necrosis Virus (IHHNV), Monodon Baculovirus (MBV), Hepatopancreatic Parvovirus (HPV), Yellow Head Virus (YHV), Gill-associated Virus (GAV), Taura Syndrome Virus (TSV) and Infectious Myonecrosis Virus (IMNV), (Claydon et al., 2010). Due to WSV large scale mortalities were occurring in shrimp culture ponds in most major producing countries and about 400-600 crore US\$ of economic losses have been estimated in Asia and more than 100 crore US\$ in America, between 1992 and 2001 and presently the disease has spread worldwide.

Many shrimp diseases are new or newly emerged in Asia such as Acute Hepatopancreatic Necrosis Disease (AHPND) or Early Mortality Syndrome (EMS), Hepatopancreatic Haplosporidiosis (HPH), Aggregated Transformed Microvilli (ATM) and Covert Mortality Disease (CMD) leads to serious economic losses to the shrimp industry. In addition to these, White Spot Disease (WSD), Yellow Head Disease (YHD) and Infectious Myonecrosis (IMN) including
Hepatopancreatic Microsporidiosis (HPM) continued their share of losses (Thitamadee et al., 2016).

The Global Aquaculture Alliance (GAA, 2013) has estimated that losses to the Asian shrimp culture sector amount to US\$ 1.0 billion. World farmed shrimp production volumes decreased in 2012 and particularly in 2013, mainly as a result of disease-related problems, such as Early Mortality Syndrome (EMS) (FAO, 2014).

In India, White Spot Disease (WSD), Loose Shell Syndrome (LSS) and slow growth have been primarily responsible for economic losses to the shrimp ( $P$. monodon) farming sector. The production loss due to slow growth and white gut disease was estimated to be $5726 \mathrm{mt}$ amounting to Rs. 120 crores per year (about US\$ 21.64 million annually) (Kalaimani et al., 2009; Ayyappan et al., 2009).

Kalaimani et al., (2013) reported that the gross national losses in India due to shrimp diseases was estimated at $48717 \mathrm{mt}$ of shrimp valued at more than Rs. 1000 crores, and employment of 2.15 million man days. The major diseases which are causing economic losses are White Spot Syndrome Virus (WSSV), Loose Shell Syndrome (LSS) and combination of WSSV and LSS, white gut and slow growth syndrome in that order at national level. Additional price loss was also recorded on account of poor quality of final output like deformed organs, loose shell and muddy smell.

Diseases such as White Spot Syndrome Virus (WSSV), Black Gill Disease (BGD), Running Mortality Syndrome (RMS), Loose Shell Syndrome (LSS), White Faecal Syndrome (WFS), White Muscle Disease (WMD), Infectious Hypodermal and Haematopoietic Necrosis (IHHN) (Srinivas et al., 2016) and Hepatopancreatic Microsporidiosis (HPM) 
(Rajendran et al., 2016; Tang et al., 2016; Suresh et al., 2018; Raveendra et al., 2018) in shrimps causing economic loss to the aquaculture industry.

The intensification of shrimp aquaculture produced a number of problems affecting the industry (Flegel 1997; Alabi, Latchford and Jones 2000). These include environmental and physiological stress factors that are often related to disease and mortality; these elements have been related to an increased susceptibility to infectious diseases (Lightner and Redman 1998). Viral diseases have emerged during the past two decades as serious economic impediments to successful shrimp farming. While nearly 20 distinct viruses or groups of viruses are known to infect shrimp culture; White Spot Syndrome Virus (WSSV), Yellow Head Virus (YHV), Infectious Hypodermal and Hematopoietic Necrosis Virus (IHHNV), and Taura Syndrome Virus (TSV) pose a threat to the future of shrimp culture. Among all these WSSV has become the biggest threat and huge economic loss in shrimp industry (Lightner, 1999).

More recently, shrimp farms in Asia and other areas have been reporting significant economic losses in L. vannamei culture as they were infected with a microsporidian parasite, Enterocytozoon hepatopenaei (EHP) due to severe growth retardation (Newman, 2015; Thitamadee et al., 2016).

Production losses in shrimp culture due to EHP have been reported to be increasing over the last two years as effective control measures are not available (Giridharan, and Uma, 2017; Suresh et al., 2018; Raveendra et al., 2018).

Stunting of $L$. vannamei in shrimp culture ponds for various reasons including EHP has created confusion among shrimp farmers and farmers are unable to harvest the crop though it is uneconomical to continue the crop with stunted shrimp (Raveendra et al., 2018).

The economic losses attributed to EHP infection have been rapidly growing and EHP is now considered to be a critical threat to shrimp aquaculture. Disease surveillance carried out by ICAR-CIBA has indicated that EHP was present in $15.6 \%$ of over 100 farms investigated. Further ICAR-CIBA (2016) report opined that more work is required to have a clear understanding of its role in growth retardation/white feces syndrome and its morbidity potential to influence mortality and also the effect of this parasite on pond profitability.

Considering the economic losses by EHP infection to the shrimp industry, the study was aimed to evaluate the economic importance of this parasite on pond profitability.

\section{Materials and Methods}

\section{EHP infected ponds}

The shrimp (L. vannamei) ponds which were experienced with white feces syndrome and slow (stunted or retarded) growth were selected from different shrimp farms located in Nidiguntapalem (Pond no. 1) of Muthukur mandal, Pantapalem (Pond no. 2) of Muthukur mandal, Dugarajapatnam (Pond no. 3), Tupilipalem (Pond no. 4) of Vakadu mandal, Mudivarthi (Pond no. 5) village of Vidavaluru mandal, SPSR Nellore district, Andhra Pradesh, India.

\section{Healthy Ponds}

Five (5) ponds have selected for estimating the economical impact between EHP infected or slow growth and disease free which were located in Karlapudi (Pond no. 1), Dugarajapatnam (Pond no. 2), Kolanukuduru 
(Pond no. 3), Kolanukuduru (Pond no. 4), Konduru (Pond no. 5). The ponds were having satisfactory biosecurity facilities. Crab fencing and bird netting was done before pumping water to prevent the auto entrants. The filter bags were checked properly, which was fitted to the inlet and outlet pipe, then the pumping was done to the entire ponds. After filling water kept stand one day without any disturbance for sedimentation. Subsequently the water was chlorinated (60 ppm/ha) after that excess chlorine was neutralized by dechlorination process which took 72 hours. After dechlorination, the water enriched with probiotic for the good beneficial bacterial environment.

The L. vannamei seeds (post larval stage 12, that had been acclimated to a salinity level of 17 ppt for Karlapudi (Pond no. 1), and 35 ppt for Dugarajapatnam (Pond no. 2), $25 \mathrm{ppt}$ Kalanukuduru (Pond no. 3), 25 Kolanukuduru (Pond no. 4) and 25 ppt for Konduru (Pond no. 5) confirmed negative for the white spot syndrome virus(WSSV) and Enterocytozoon hepatopenai (EHP) by the polymerase chain reaction (PCR), were purchased from Technomin hatchery, Govindapalli, BMR Claswin hatchery, Chennai, CP Aquaculture India Private Ltd, hatchery, Pondichery and CP Aquaculture India Private Ltd, hatchery Gudur respectively.

The seeds were transported in oxygenated double-layered polythene bags with crushed ice packs between inner and outer covers of the bag to maintain optimum temperature in turn to keep less stress to the shrimps and the entire set up was packed in a carton. The seeds were brought to the farm site and bags were kept in the pond water for some time to adjust the temperature. Then the pond water was added slowly into the seed bag to adjust the salinity and $\mathrm{pH}$. Subsequently the seeds were released slowly in to the ponds. All the ponds were stocked with a density of $50 / \mathrm{m}^{2}$.
From the 60th days of culture (DOC) onwards cast net (sampling) was used weekly for monitoring shrimp health and growth. The water level was measured by using a standard scale with $\mathrm{cm}$ marking. The water quality parameters like salinity, $\mathrm{pH}$, temperature, dissolved oxygen and light transparency were measured by using hand refractometer, $\mathrm{pH}$ pen, thermometer, and dissolved oxygen meter and secchi disc, respectively. Aeration was given to the entire culture period for all ponds. Totally $16 \mathrm{hp}$ aerators were fixed for each culture pond. The aerators were placed in such a way that it could dissolve maximum dissolved oxygen (DO) into the pond water and makes the culture environment friendly. Average daily growth (ABG), Average body weight (ABW) and Feed conversion ratio (FCR) was observed throughout the study period with 7 days interval. FCR and ADG were calculated by the given formula below

FCR $=$ Total weight of the harvested shrimps / total feed used

ADG = Total weight gained by the shrimps / Total days of culture

\section{Primers}

Published universal primers were used for the amplification of ssu rRNA gene of Enterocytozoon hepatopenaei isolates. The names of the primers, sequence and amplification size are given in Table 1.

\section{Collection of samples}

Five (5) ponds were selected for the study, which were experiencing size variation/growth retardation and white feces syndrome in order to compare the production cost with healthy ponds. On each sampling day, a minimum of 60 shrimps were examined for diseases of species as per OIE guidelines (OIE, 2013). Information on behavioral abnormalities, 
gross and clinical signs were recorded on the sampling sheet. From each pond 2-4 shrimps were taken for diagnosis and the hepatopancreas of each sample were dissected out and fixed in Davidson's fixative for histopathology and along with Davidson's fixative some samples were separately fixed in 95\% alcohol for molecular diagnosis (Bell and Llightner, 1988). Whole infected shrimps were also wrapped individually in sterile polythene bags, placed in icebox and brought to the laboratory. On reaching laboratory they were transferred to refrigerator and analyzed / processed.

\section{Histopathology}

Histopathology was conducted in the Department of Veterinary Pathology, College of Veterinary Science, Sri Venkateswara Veterinary University, Titupati. The hepatopancreas of infected and normal shrimps were fixed in alcoholic Davidson's fixative for 48-72 $\mathrm{h}$ for comparative study. After fixation the tissues were transferred to $70 \%$ ethyl alcohol and kept overnight. Histopathological analysis was made as described by Roberts (2001).

\section{Molecular diagnosis}

Molecular diagnosis has done at OIE Reference Laboratory for WTD, Department of Zoology, C. Abdul Hakeem College, Melvisharam, Tamil Nadu.

\section{DNA extraction}

Hepatopancreas were homogenized in NTE buffer $(0.2 \mathrm{M} \mathrm{NaCl}, 0.02 \mathrm{M}$ Tris $-\mathrm{HCl}$ and $0.02 \mathrm{M}$ EDTA, $\mathrm{pH}$ 7.4), and $10 \%$ tissue suspension was made. The suspension was centrifuged at $3000 \mathrm{~g}$ for $15 \mathrm{~min}$ at $4{ }^{\circ} \mathrm{C}$, and supernatant was collected. The tissue suspension was mixed with an appropriate amount of digestion buffer $(100 \mathrm{mM} \mathrm{NaCl}, 10$
mM Tris- $\mathrm{HCl}, \mathrm{pH}$ 8.0, 50 mM EDTA, $\mathrm{pH}$ 8.0, $0.5 \%$ sodium dodecyl sulphate and $0.1 \mathrm{mg}$ $\mathrm{mL}^{-1}$ proteinase $\mathrm{K}$ ) and incubated for $2 \mathrm{~h}$ at $65^{\circ} \mathrm{C}$ to extract the DNA. After incubation, the digests were deproteinized by successive phenol/chloroform/isoamyl alcohol extraction and DNA was recovered by ethanol precipitation and dried. The dried DNA pellet was suspended in TE buffer and used as a template for PCR amplification.

The reaction mixture consisted of $1 \mu \mathrm{L}$ of template DNA, $1 \mathrm{mM}$ of each primer, $200 \mathrm{mM}$ of deoxynucleotide triphosphate and $1.25 \mathrm{U}$ of DNA Taq polymerase in PCR buffers supplied with a commercially available kit. The mixture was incubated for 35 cycles in an automatic thermal cycler.

The PCR components were mixed and spinned shortly. The PCR reaction was set with the amplification condition as mentioned below. A total of 35 amplification cycles were performed.

\section{Agarose gel electrophoresis}

Polymerase chain reaction products were analyzed by electrophoresis in $0.8 \%$ agarose gels stained with ethidium bromide and visualized by ultraviolet transillumination.

\section{DNA Sequencing and analysis}

The amplified PCR product was purified using Qiagen plasmid minipreparation spin column. Sequence analysis was performed on an Autoread Sequencing kit (Applied Biosystems). The nucleotide sequence of $E$. hepatopenaei (small subunit rRNA gene) has been deposited in (Gen-Bank accession no. KU198278). The sequence was aligned using bioinformatics tools such as standard nucleotide BLAST and multiple sequence analysis clustalW (Thompson, Higgins and Gibson 1994). Significant similarity with sequences available 
in GenBank was searched using BLAST at National Center for Biotechnology Information (NCBI).

\section{Challenge studies}

The challenging study was conducted in Wet Laboratory of the Department of Aquatic Animal Health Management, College of Fishery Science, Sri Venkateswara Veterinary University, Muthukur, Nellore. To determine, if EHP can be transmitted to healthy $L$. vannamei by oral ingestions, shrimp samples (20 numbers) from normally growing pond with biosecurity facility with an average body weight $7 \mathrm{gm}$ were collected and brought to the laboratory. The shrimps were conditioned and starved for $48 \mathrm{hrs}$. From $3^{\text {rd }}$ day onwards 5 animals were separated and fed with hepatopancreatic tissue which is collected from shrimp affected by slow growth/EHP and WFS. The infected shrimps were processed for histopathology and molecular diagnosis.

\section{Statistical analysis}

Two sample t-test was applied to know the significance difference between parameters like $\mathrm{ABW}$, survival \%, biomass of harvested shrimp, FCR and ADG of infected and healthy ponds.

\section{Results and Discussion}

\section{Clinical signs of infected shrimp}

The shrimp samples collected from EHP infected ponds which were experiencing white feces syndrome affected ponds were showing floating strands of white feces and some time the fecal strand was hanging from the anal portion of the shrimp. When the problem was severe, all the floating fecal strands were coming to sides of the pond, and it became easy for the pond manager to recognize the abnormality. Associated with the white feces syndrome is drop in daily feed consumption, slow growth and some shrimp mortality also. The freshly dead shrimp also showed loose shell condition. During the study period, the white feces syndrome first appears 50-70 days of culture (DOC). After the appearance of white feces, shrimp health will deteriorate if some management interventions are not adopted In general, the shrimp in the WFS ponds showed FCR of over 2.92-3.17 (can be considered as 3.0) as compared to the range of normal growth ponds 1.83-1.94 (can be considered as 1.9).

\section{Effect of EHP on pond profitability}

The present study attempts to focus some light on the actual economic loss encountered by the shrimp farmers from the slow growing EHP affected and either associated with white feces syndrome or not. For this study five farm pond production effected by both EHP and white feces syndrome were compared with 5 normally (healthy) performed shrimp population with biosecured environment by adopting better management practices (BMPs). The performance details are furnished in Table 2 and 3.

The normally (healthy) performed shrimp ponds culture duration (days of culture DOC) ranged from 115-121. Generally also any farm pond normal culture duration will be 120 days only. So, all these five ponds almost completed their culture duration of 120 days. All the five ponds recorded 40 count (40 pieces per $\mathrm{Kg}$ ) production (Table 3). But survival was nearly $50 \%$ only.

Without exception all the shrimp ponds recorded average daily growth (ADG) of 0.2 gram per day. With 360 rupees price per $\mathrm{Kg}$ of 40 count (40 shrimps per $\mathrm{Kg}$ ) shrimp, these pond recorded gross sales of shrimp ranging from 19-22 lakh rupees. The average cost of production per $\mathrm{Kg}$ was 215 rupees. 
Interestingly the infected ponds covered in this study were having culture duration 100-160 days i.e. beyond the normal culture period. The average daily growth (ADG) of infected shrimp ranged from 0.1-0.16 grams (Table 2) and average body weight $(\mathrm{ABW})$ at harvest was ranging from 10-25 grams (Table 2). The cost of production per $\mathrm{kg}$ difference between these two categories was 140 rupees i.e. cost of production alone increased by 140 rupees. This 140 rupees were to be enjoyed by the farmer had it been normal healthy shrimp population. Out of the five EHP infected studied for the pond profitability, two ponds (Pond no. 1 and Pond no. 4) recorded profitability of above 1 lakh rupees only (Table 4), while the normal healthy pond recorded net profit in the range of 7-9 lakh rupees (Table 5). Pond no. 2, Pond no.3 and Pond no. 5 recorded loss ranging from 3.64.3lakh rupees per pond.

\section{Histopathology}

Histologically, large eosinophilic to basophilic inclusions indicating presumptive developmental stages of the microsporidian could be noticed in the tubular epithelium (Fig. 1). These stages were predominantly seen in the distal ends of hepatopancreatic tubules and most of the tubular epithelium in this region showed detachment from the basal membrane (Fig. 2). The basal part of the tubular epithelium showed granular material and spore-like structures. In some of the sections, the spores were noticed in vacuolated structures. Sloughing of the tubular epithelial cells was pronounced in heavily infected HP and large spore aggregations were noticed in the tubular lumen.

\section{Molecular characterization}

In $0.8 \%$ agarose gel electrophoresis, samples with EHP infection show a band of PCR (510 bp) (Fig. 3). Shrimp samples from the five ponds were tested for EHP infection. Selected microsporidian isolate of Enterocytozoon hepatopenaei KU198278 was further characterized and identified through ssu rRNA analysis. The detailed information of the bacterial strain used, host species, clinical signs, site of infection, Gen Bank accession numbers are given in below Table 6 .

\section{Oral feeding bioassay}

To determine if EHP can be transmitted to healthy L. vannamei by oral ingestions, the healthy shrimp were brought from the biosecured farm and fed with pieces of EHPinfected hepatopancreas for two days and then maintained on a commercial shrimp feed pellet for additional 22 days. Remaining shrimps were fed with commercial pellet feed only for all 30 days. During the period of challenging study, there was no mortality of animals and the challenging population did not show either white gut or white fecal excretion. The experimental animals in both experiments (infecting and control) were examined twice a day for gross signs of disease. The shrimp were collected at 5,10 and 15 day postchallenge (d p.c.) for detection of $E$. hepatopenaei in hepatopancreas by histopathology and PCR. The results showed that EHP was not detected in samples collected on day 5 post feeding. EHP was detected in shrimp collected on day 10. Histological analysis showed 2 shrimp collected at day 15 were infected by EHP, as basophilic inclusion bodies and mature spores were found in their hepatopancreas tissue.

\section{Growth Parameters}

Considering the performance of infected and disease free shrimp ponds a two sampled Ttest had been conducted to evaluate the significant difference of various parameters like ABW, shrimp biomass, survival \%, FCR and $\mathrm{ADG}$. 


\section{DNA extraction}

\begin{tabular}{|c|c|c|c|c|c|c|c|c|}
\hline Initial denaturation & Dens & ation & \multicolumn{2}{|c|}{ Annealing } & \multicolumn{2}{|c|}{ Extension } & \multicolumn{2}{|c|}{ Final extension } \\
\hline $2 \mathrm{~min}$ & $94^{\circ} \mathrm{C}$ & $30 \mathrm{sec}$ & $58^{\circ} \mathrm{C}$ & $1 \mathrm{~min}$ & $72^{\circ} \mathrm{C}$ & $1 \mathrm{~min}$ & $72^{\circ} \mathrm{C}$ & $5 \mathrm{~min}$ \\
\hline 1 cycle & & & \multicolumn{2}{|c|}{35 cycles } & & & \multicolumn{2}{|c|}{1 cycle } \\
\hline
\end{tabular}

Table.1 Names of the primers, sequence and amplification size

\begin{tabular}{|c|l|c|c|}
\hline Primers & Sequence $\left(\mathbf{5}^{\prime}-\mathbf{3}^{\prime}\right)$ & Amplification size & Reference \\
\hline EHIP-510F & GCC TGA GAG ATG GCT CCC ACG T & 510-bp & Tang et al., \\
\hline EHP-510R & GCG TAC TAT CCC CAG AGC CCG A & & 2015 \\
\hline
\end{tabular}

Table.2 Performance details of the EHP infected ponds

\begin{tabular}{|l|l|l|l|l|l|}
\hline Details & Pond No. 1 & Pond No. 2 & Pond No. 3 & Pond. No 4 & Pond. No 5 \\
\hline Area (Ha) & 1 & 1 & 0.8 & 0.8 & 0.8 \\
\hline Initial Stocking (numbers) & 400000 & 500000 & 400000 & 400000 & 500000 \\
\hline Density (Numbers/m²) & 40 & 50 & 50 & 50 & 62.5 \\
\hline Stocking Date & 18 -Oct-2015 & 19 -Feb-2016 & 19 -Mar-2016 & 5-Mar-2016 & 27-Mar-2016 \\
\hline Harvest Date & $27-M a r-2016$ & $20-J u n-2016$ & $27-J u n-2016$ & $12-$-Aug-2016 & $15-J u l-2016$ \\
\hline Culture Period (days) & 160 & 121 & 100 & 160 & 110 \\
\hline ABW (g) & 25 & 12.5 & 10 & 20 & 11.1 \\
\hline Count (Numbers/Kg) & 40 & 80 & 100 & 50 & 90 \\
\hline Shrimp Biomass Harvest (Kg) & 4635 & 3300 & 2240 & 4100 & 2900 \\
\hline Survival (\%) & 46.35 & 52.8 & 56 & 51.25 & 52.2 \\
\hline Total Feed used (Kg) & 14300 & 10200 & 6550 & 12750 & 9200 \\
\hline FCR & 3.08 & 3.09 & 2.92 & 3.10 & 3.17 \\
\hline ADG & 0.16 & 0.103 & 0.1 & 0.125 & 0.101 \\
\hline Production Kg/Ha & 4635 & 3300 & 2800 & 5125 & 3625 \\
\hline
\end{tabular}

Table.3 Performance details of the Healthy ponds

\begin{tabular}{|l|l|l|l|l|l|}
\hline Details & Pond 1 & Pond 2 & Pond 3 & Pond 4 & Pond 5 \\
\hline Area (Ha) & 1 & 0.8 & 1 & 1 & 0.8 \\
\hline Initial Stocking (numbers) & 500000 & 400000 & 500000 & 500000 & 400000 \\
\hline Density (Numbers/m²) & 50 & 50 & 50 & 50 & 50 \\
\hline Stocking Date & 6-Mar-2016 & $17-$-Mar-2016 & 10 -Mar-2016 & $\begin{array}{l}19-\text {-Mar- } \\
2016\end{array}$ & 22-Mar-2016 \\
\hline Harvest Date & 5-Jul-2016 & $15-J u l-2016$ & $10-J u l-2016$ & $17-J u l-$ & $20-J u l-2016$ \\
& & & & 2016 & \\
\hline Culture Period (days) & 121 & 119 & 121 & 119 & 115 \\
\hline ABW (g) & 25 & 25 & 25 & 25 & 25 \\
\hline Count (Numbers/Kg) & 40 & 40 & 40 & 40 & 40 \\
\hline Shrimp Biomass Harvest (Kg) & 6120 & 5340 & 6220 & 6290 & 5250 \\
\hline Survival (\%) & 48.96 & 53.4 & 49.76 & 50.32 & 52.5 \\
\hline Total Feed used (Kg) & 11220 & 10200 & 11450 & 11660 & 10220 \\
\hline FCR & 1.83 & 1.91 & 1.84 & 1.85 & 1.94 \\
\hline ADG & 0.206 & 0.210 & 0.206 & 0.210 & 0.217 \\
\hline Production Kg/Ha & 6120 & 6675 & 6220 & 6290 & 6562.5 \\
\hline
\end{tabular}


Table.4 Cost analysis for EHP Infected Ponds

\begin{tabular}{|l|l|l|l|l|l|}
\hline Details & Pond No 1 & Pond No 2 & Pond No 3 & Pond No 4 & Pond No 5 \\
\hline Seed cost & 120000 & 150000 & 100000 & 120000 & 150000 \\
\hline Feed cost & 1072500 & 765000 & 491250 & 956250 & 690000 \\
\hline Pond preparation cost & 10000 & 10000 & 9500 & 9500 & 9500 \\
\hline Water treatment cost & 24000 & 18000 & 18000 & 16000 & 18000 \\
\hline Feed probiotic cost & 8500 & 6500 & 5000 & 8000 & 8500 \\
\hline Water probiotic & 16000 & 12000 & 10500 & 16000 & 9500 \\
\hline Bottom probiotic cost & 22500 & 16000 & 13300 & 20500 & 14800 \\
\hline Carbon source cost & 6950 & 5150 & 3900 & 6500 & 4290 \\
\hline Chemicals cost & 21500 & 16100 & 13400 & 19800 & 14350 \\
\hline Feed supplement cost & 4980 & 3200 & 2200 & 4600 & 3850 \\
\hline Diesel cost & 40000 & 31000 & 26000 & 40000 & 28000 \\
\hline Electricity cost & 147930 & 105900 & 74800 & 145300 & 77100 \\
\hline Labour cost & 37500 & 30000 & 25000 & 38000 & 28000 \\
\hline Maintenance and repair & 15800 & 12000 & 9900 & 15000 & 9900 \\
\hline Other expenses & 16000 & 10500 & 8750 & 15500 & 9000 \\
\hline Total production cost (Rs) of shrimp & 1564160 & 1191350 & 811500 & 1430950 & 1074790 \\
\hline Total production cost (Rs) per Kg & 337 & 361 & 362 & 349 & 370 \\
\hline Material price (Rs) & 1668600 & 792000 & 448000 & 1558000 & 638000 \\
\hline Profit/Loss & $(+) 104440$ & $(-) 399350$ & $(-) 363500$ & $(+) 127050$ & $(-) 436790$ \\
\hline
\end{tabular}

Table.5 Cost analysis for healthy ponds

\begin{tabular}{|c|c|c|c|c|c|}
\hline Details & Pond 1 & Pond 2 & Pond 3 & Pond 4 & Pond 5 \\
\hline Seed cost & 150000 & 120000 & 150000 & 150000 & 120000 \\
\hline Feed cost & 841500 & 765000 & 858750 & 874500 & 766500 \\
\hline $\begin{array}{l}\text { Pond preparation } \\
\text { cost }\end{array}$ & 25000 & 18000 & 25000 & 25000 & 18000 \\
\hline Water treatment cost & 28000 & 24500 & 29800 & 28900 & 2400 \\
\hline Feed probiotic cost & 7300 & 6940 & 9950 & 10060 & 6800 \\
\hline Water probiotic & 12000 & 10000 & 12000 & 12000 & 10000 \\
\hline $\begin{array}{l}\text { Bottom probiotic } \\
\text { cost }\end{array}$ & 18000 & 15500 & 19800 & 18500 & 16000 \\
\hline Carbon source cost & 9800 & 9600 & 9950 & 11350 & 9900 \\
\hline Chemicals cost & 15900 & 14950 & 1830 & 16350 & 13150 \\
\hline $\begin{array}{l}\text { Feed supplement } \\
\text { cost }\end{array}$ & 3340 & 2990 & 3290 & 3270 & 3050 \\
\hline Diesel cost & 31000 & 29000 & 32000 & 31150 & 29500 \\
\hline Electricity cost & 110950 & 96000 & 113200 & 112590 & 93800 \\
\hline Labor cost & 32000 & 30000 & 32000 & 34000 & 30000 \\
\hline $\begin{array}{l}\text { Maintenance and } \\
\text { repair }\end{array}$ & 15000 & 12000 & 15000 & 14500 & 13000 \\
\hline Other expenses & 10000 & 10000 & 10000 & 10000 & 10000 \\
\hline $\begin{array}{l}\text { Total production } \\
\text { cost (Rs) of shrimp }\end{array}$ & 1309790 & 1164480 & 1322570 & 1352170 & 1142100 \\
\hline $\begin{array}{l}\text { Total production } \\
\text { cost }(\mathbf{R s}) \text { per Kg }\end{array}$ & 214 & 218 & 212 & 214 & 217 \\
\hline Gross Profit (Rs) & 2203200 & 1922400 & 2239200 & 2264400 & 1890000 \\
\hline Net Profit (Rs) & 893410 & 757920 & 916630 & 912230 & 747900 \\
\hline
\end{tabular}


Table.6 Detailed information of the bacterial strain used, host species, clinical signs, site of infection, Gen Bank accession numbers

\begin{tabular}{|l|l|l|l|l|l|}
\hline Shrimp species & Disease/Clinical sign & $\begin{array}{l}\text { Site of } \\
\text { infection }\end{array}$ & $\begin{array}{l}\text { Length of } \\
\text { consensus } \\
\text { sequence (bp) }\end{array}$ & $\begin{array}{l}\text { Gen Bank } \\
\text { Accession } \\
\text { number }\end{array}$ & $\begin{array}{l}\text { Identificatio } \\
\text { n }\end{array}$ \\
\hline $\begin{array}{l}\text { Litopenaeus } \\
\text { vannamei }\end{array}$ & $\begin{array}{l}\text { Stunted growth/White } \\
\text { feces Syndrome }\end{array}$ & $\begin{array}{l}\text { Hepato } \\
\text { pancreas }\end{array}$ & $\mathbf{5 1 0}$ & KU198278 & EHP \\
\hline
\end{tabular}

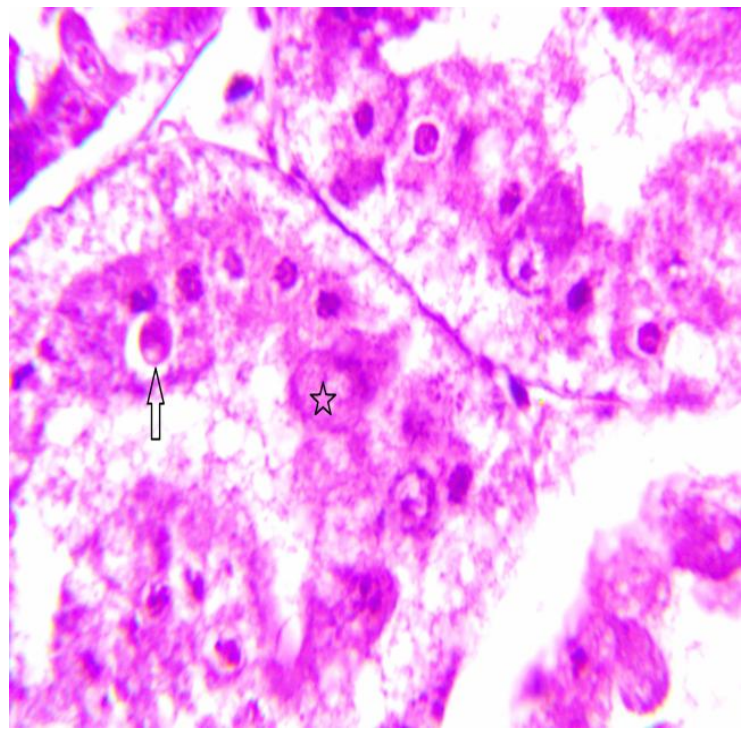

Fig.1 Basophilic inclusion (arrow; HandE $x 400$ ), EHP spores (star; HandE, $x 400$ ) in the degenerated tubular lumen

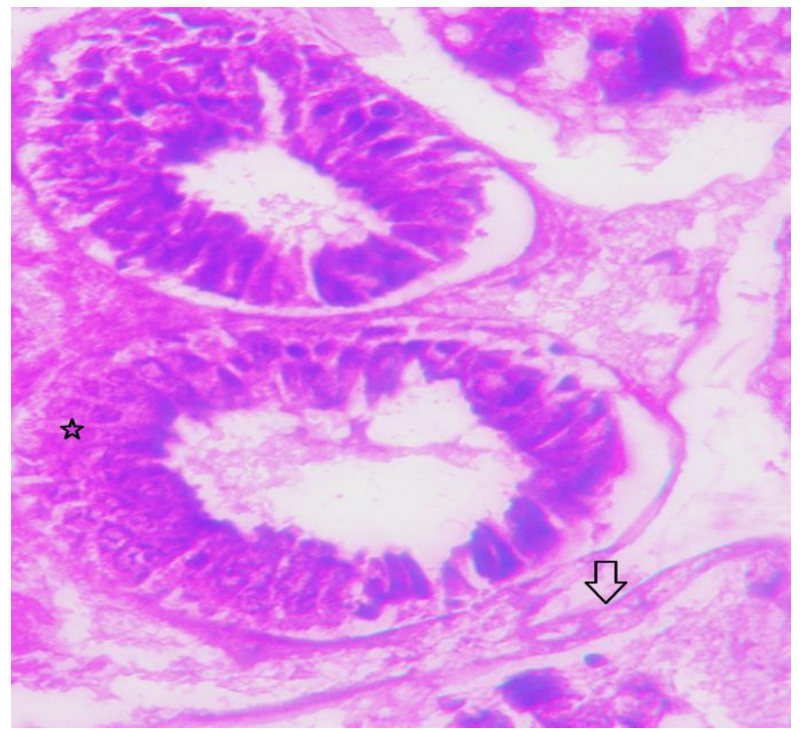

Fig.2 Developmental stages of EHP spores (star) and detachment of tubular lumen from the basement membrane (arrow) (HandE, $\mathrm{x} 400)$

Fig.3 0.8\% Agarose gel showing PCR product of EHP of experimentally infected Litopenaeus vannamei

\section{PCR Result}

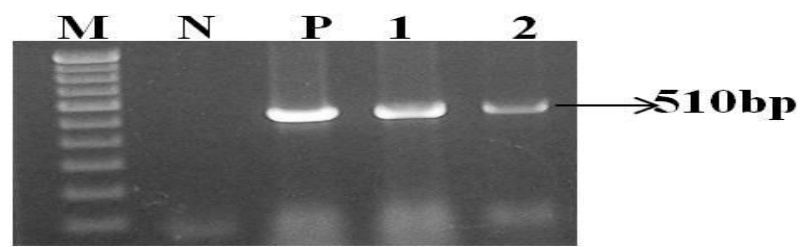

\section{Lane M - DNA 100bp Marker \\ Lane $\mathbf{N}$ - Negative Control \\ Lane P - Positive Control \\ Lane 1 - Pond Sample 1 \\ Lane 2 - Pond Sample 2}




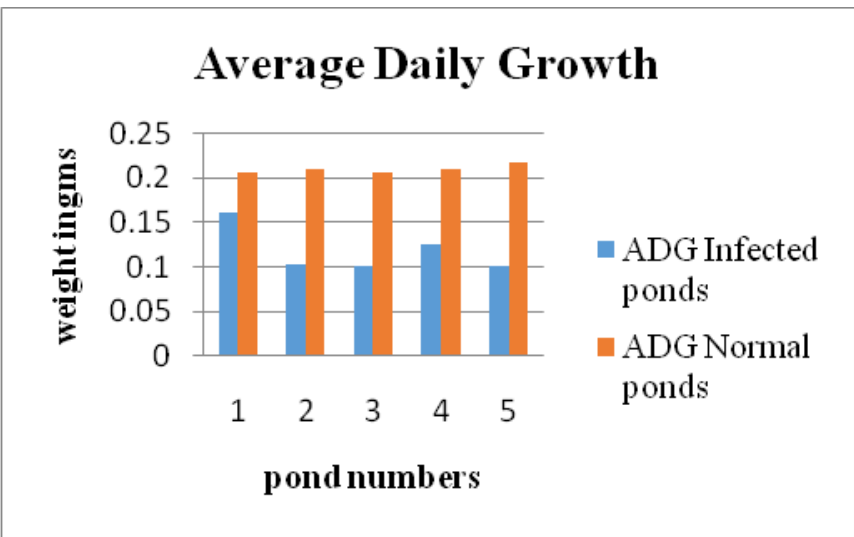

Fig.4 Average daily growth between infected and normal ponds

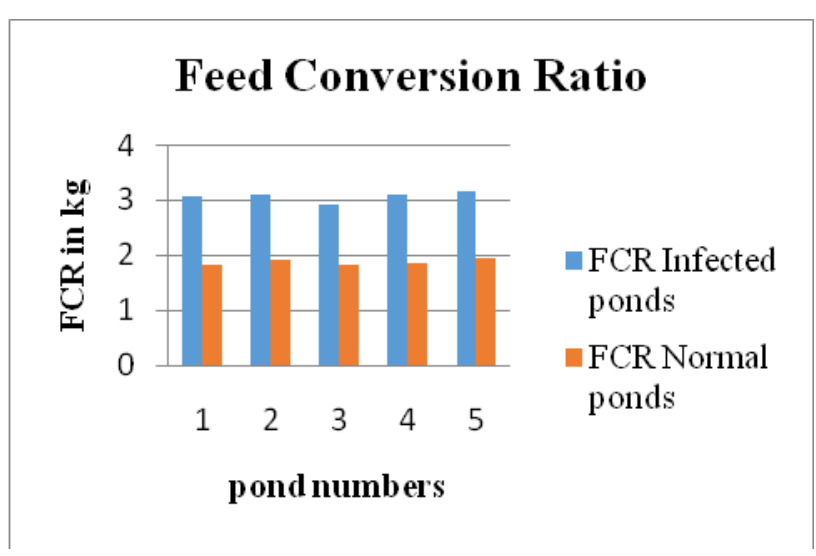

Fig.5 FCR between infected and normal ponds

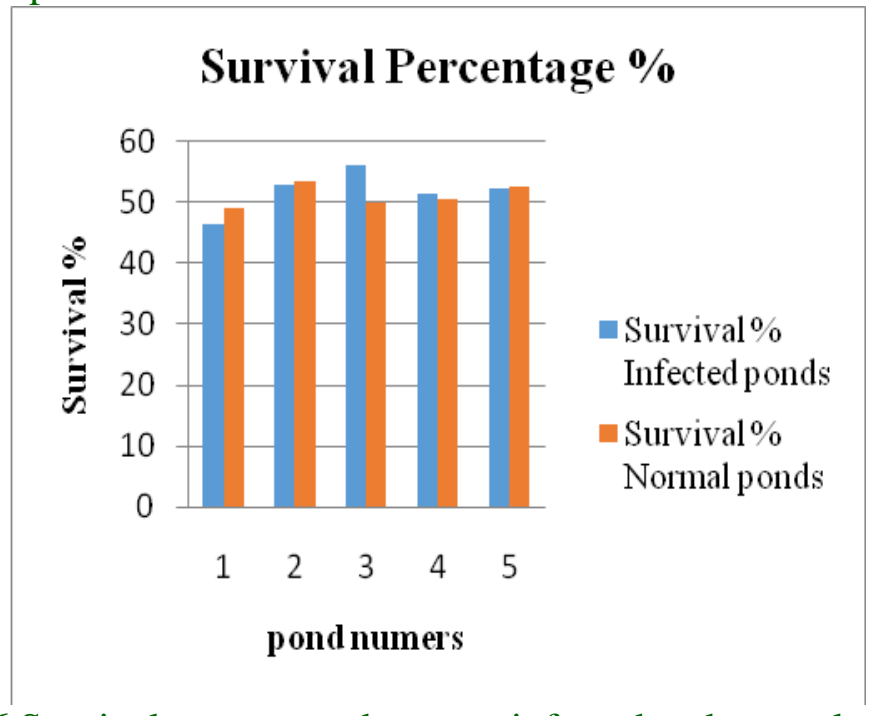

Fig.6 Survival percentage between infected and normal ponds

Average body weight, Shrimp biomass, ADG (Fig. 4) and FCR (Fig. 5) of infected shrimp ponds showed appreciable significance at 5\% level when compared to the healthy shrimp ponds. Shrimp biomass, FCR and ADG showed similar level of significance at $1 \%$ level, in conjunction to $5 \%$ whereas, percentage of survivability (Fig. 6) remained insignificant at both the levels.

In all cases of EHP infected ponds DOC (days of culture) is very high when compared with growth. Relatively production cost is more when compared with material cost or Biomass cost. But in case no 1 and 4, harvested count is 40 and 50, so production cost is almost all equal to material cost.

Marine shrimp farms in Southeast Asia and other areas have been increasingly reporting stocks that exhibit severely retarded growth and shrimp from affected ponds were found to be heavily infected with the microsporidium, Enterocytozoon hepatopenaei (EHP) (Tourtip et al., 2009; Sritunyalucksana el al., 2014), a parasite of penaeid shrimp. EHP has been found in several shrimp farming countries in Asia including Vietnam, China, Indonesia, Malaysia and Thailand (Tang et al., 2015) and very recently, its occurrence was reported in farm reared L. vannamei in India (Sritunyalucksana el al., 2014; Rajendran et al., 2016; Santhoshkumar et al., 2016; Suresh 
et al., 2018; Raveendra et al., 2018). The economical losses attributed to EHP infection have been rapidly growing and EHP is now considered to be a critical threat to shrimp aquaculture.

\section{Effect of EHP on pond profitability}

In this study, as part of better management practices (BMPs) by biosecured (healthy) ponds, mixing of garlic paste, bitter gourd paste and onions paste with turmeric powder (freshly prepared) at the rate of 10 grams per $\mathrm{Kg}$ feed to prevent EHP infection and also to enhance immune response. This is similar to reports of Suresh et al., 2018; Raveendra et al., 2018.

In the present study, the pond water quality parameters from ponds showing typical clinical symptoms for white feces syndrome and slow growth and normal ponds with healthy shrimp population did not show any qualitative variations in important parameters such as water temperature, $\mathrm{pH}$ and Dissolved Oxygen. Also from the published literature so far on EHP, the pond water quality was not suspected for influencing either of the two causes.

Though the clinical signs of shrimp associated with white feces syndrome (WFS) were not showing any other clinical signs, the smaller number of daily shrimp mortality and sometime associated with loose shell further associated with dropping daily feed consumption by the surviving population of the shrimp indicated that white feces syndrome has also shared the major economic loss experienced in shrimp pond production along with slow growth. Similar results were reported by Tang et al., (2016) and stated that WFS has caused significant economic losses to shrimp farmers, because affected populations exhibited elevated food conversion ratio (high FCR), growth retardation and highly variable sizes of individual shrimp at harvest. Further they reported that the white feces are composed, almost completely of massive quantities of EHP spores, gut mucus, remnants of sloughed tissues from hepatopancreas tubules infected with EHP and rod shaped bacteria. And also reported that the possibility of white feces syndrome from a severe EHP infection in shrimp.

\section{Oral feeding bioassay}

The experimental study carried out confirmed the propagation of infections as contagious and the selection of hepatopancreatic tissue was based on the first report on Enterocytozoan hepatopenaei (EHP) by Tourtip et al., (2009). The experimental studies by Tang et al., (2016) also confirmed this contagious nature both by per os bioassay as well as cohabitation bioassay. In this study challenged shrimp recorded growth of 0.5 grams only where as normal shrimp growth of 4.2 grams for the experimental study of 30 days. This clearly confirms infection in the survived challenged shrimp population, while the growth was comparably high in unchallenged shrimps.

Santoshkumar et al., (2016), experimentally proved the tissue distribution of EHP in naturally and experimentally EHP infected $L$. vannamei. Their experimental results showed presence of EHP as strong positive in hepatopancreas, very mild positive in gut and heart and negative in haemolymph, gill, abdominal muscle and tail muscle at 5 days post challenge. Further at 10 and 20 days post challenge the PCR results were found to be similar. He also reported no increase in body weight in experimentally EHP challenged shrimp compared to 2 grams growth in normal control shrimp for the same period of observation. 
The outbreaks of microsporidian parasite Enterocytozoon hepatopenaei (EHP) or Hepatopancreatic microsporidiosis (HPM) have caused devastating economic losses and are the main causes of slow growth (stunted or retarded growth) and white feces syndrome (WFS) of shrimp Litopenaeus vannamei during the culture period. This study clearly indicated that the severity of EHP infection negatively affected the growth, but it was not affected the survival of the shrimp.

The main reason for continuation of crop infected with EHP is similar appearance of culture animal as that of normal (Healthy) one.

\section{References}

Alabi A., Latchford J. and Jones D. 2000. Demonstration of residual antibacterial activity in plasma of vaccinated Penaeus vannamei. Aquaculture 187, 15 -34

Ayyappan, S., Kalaimani, N., Ponniah, A.G. 2009. Disease status in Indian shrimp aquaculture and research efforts for better health management. Fish Chim. 29: 1321.

CIBA, 2016. Annual report 2015-16. Central Institute of Brackish Water Aquaculture, Chennai.

Flegel, T.W., 1997. Major viral diseases of the black tiger prawn (Penaeus monodon) in Thailand. World J. Microbiol. Biotechnol. 13: 433-442.

Food and Agriculture Organization (FAO). 2014. The State of World Fisheries and Aquaculture Opportunities and challenges. Rome, pp. 1-235.

Giridharan, M. and Uma, A. 2017. A Report on the Hepatopancreatic Microsporidiosis Caused by Enterocytozoon hepatopenaei (EHP) in Penaeus vannamei (Pacific White Shrimp) Farms in Thiruvallur District, Tamilnadu, India. Int.J.Curr.Microbiol. App.Sci. 6(6): 147152. doi: https://doi. org/10.20546/ijcmas.2017.606.017
Global Aquaculture Alliance (GAA). 2013. Cause of EMS shrimp disease identified. GAA News Releases. Available: http://www.gaalliance.org/ newsroom. Accessed 29 March 2014

Kalaimani, N and Ravisankar T. Final report of AP cess fund project. Chennai: Central Institute of Brackish water Aquaculture; 2009. p. 96

Kalaimani, N., Ravisankar, T., Chakravarthy, N., Raja, S., Santiago, T.C. and Ponniah, A.G. 2013. Economic Losses due to Disease Incidences in Shrimp Farms of India. Fish. Techn. 50: 80-86

Kiran, P.R. B. and Shyam, S. S. 2012. Shrimp Aquaculture: Diseases, Health Management, Exotic Introduction and Regulations. In: World Trade Agreement and Indian Fisheries Paradigms: A Policy Outlook, Kochi, pp. 17-26

Klinger, R.E. and Floyd, R.F. 2002. Introduction of fresh water fish parasites EDIS-Electronic Data Information Source: /IFAS Extension. University of Florida. http: //edis.ifas.ufl.edu/FA033

Lightner D.V. 1999. The penaeid shrimp viruses TSV, IHHNV, WSSV, and YHV: current status in the Americas, available diagnostic methods, and management strategies. Journal of Applied Aquaculture 9, 27

Newman, S.G. 2015. Microsporidian impacts shrimp production-Industry efforts address control, not eradication. Global Aquaculture Advocate, March/April 2015, 16-17

Rajendran, K.V., Shivam, S., Praveena, P.E., Sahayakajan, J.J., Kumar, T.S., Avunje, S., Jagadeesan, V., Babu, P.S.V.A.N.V., Prande, A., Krishnan, A.N., Alavandi, S.V. and Vijayan, K.K. 2016. Emergence of Enterocytozoon hepatopenaei (EHP) in farmed Penaeus (Litopenaeus) vannamei in India. Aquaculture. 454: 272-280.

Raveendra, M., P. Hari Babu, T. Neeraja, D. Pamanna, N. Madhavan, A.S. Sahul Hameed and Srilatha, C.H. 2018. Screening for Incidence of Microsporidian Parasite Enterocytozoon 
hepatopenaei (EHP) in Litopenaeus vannamei from Aquaculture Ponds in SPSR Nellore District of Andhra Pradesh, India. Int.J.Curr.Microbiol. App.Sci. 7(03): 1098-1109.

Santhoshkumar, S., Sivakumar, S., Vimal, S., Abdul Majeed, S., Taju, G., Haribabu, P., Uma, A. and Sahul Hameed, A.S. 2016. Biochemical changes and tissue distribution of Enterocytozoon hepatopenaei (EHP) in naturally and experimentally EHP-infected whiteleg shrimp, Litopenaeus vannamei (Boone, 1931), in India. J. Fish Dis. 1-11

Sritunyalucksana, K., Sanguanrut, P., Salachan P. V., Thitamadee, S. and Flegel, T.W. 2014. Urgent appeal to control spread of the shrimp microsporidian parasite Enterocytozoon hepatopenaei (EHP). http://www.enaca.

org/modules/news/article.php?article_id= 2039.

Sriurairatana, S., Boonyawiwat, V., Gangnonngiw, W., Laosutthipong, C., Hiranchan, J. and Flegel, T.W. 2014. White feces syndrome of shrimp arises fromtransformation, sloughing and aggregation of hepatopancreatic microvilli into vermiform bodies superficially resembling gregarines. $P L O S$ ONE 9 (6): e99170.

Suresh Kummari., Divya V. Haridas, Sevok Handique, Sam Peter, C.G. Rakesh, K.G. Sneha, B. Manojkumar and Devika Pillai 2018. Incidence of Hepatopancreatic Microsporidiasis, by Enterocytozoon hepatopenaei (EHP) in Penaeus vannamei Culture in Nellore District, Andhra Pradesh, India and the Role of
Management in its Prevention and Transmission. Int.J.Curr.Microbiol. App.Sci. 7(02): 2125-2134.

Tang, K.F.J., Han, J.E., Aranguren, L.F., WhiteNoble, B., Schmidt, M.M, Piamsomboon, P. Risdiana, E. and Hanggono. B. 2016. Dense populations of the microsporidian Enterocytozoon hepatopenaei (EHP) in feces of Penaeus vannamei exhibiting white feces syndrome and pathways of their transmission to healthy shrimp. $J$. Invertebr. Pathol. 140: 1-7.

Tangprasittipap, A., Srisala, J., Chouwdee, S., Somboon, M., Chuchird, N., Limsuwan, C., Srisuvan, T., Flegel, T.W. and Sritunyalucksana, K. 2013. The microsporidian Enterocytozoon hepatopenaei is not the cause of white feces syndrome in whiteleg shrimp Penaeus (Litopenaeus) vannamei. BMC Vet. Res. 9: 139.

Thitamadee, S., Prachumwat, A., Srisala, J., Jaroenlak, P., Salachanb, P.V., Sritunyalucksana, K., Flegel, T.W. and Itsathitphaisrn, O., 2016. Review of current disease threats for cultivated penaeid shrimp in Asia. Aquaculture. 452: 69-87.

Tourtip, S., Wongtripop, S., Stentiford, G.D., Bateman, K.S., Sriurairatana, S., Chavadej, J., Sritunyalucksana, K. and Withyachumnarnkul, B. 2009. Enterocytozoon hepatopenaei sp. nov. (Microsporida: Enterocytozoonidae), a parasite of the black tiger shrimp Penaeus monodon (Decapoda: Penaeidae): fine structure and phylogenetic relationships. J. Invertebr. Pathol. 102: 21-29.

\section{How to cite this article:}

Raveendra, M., G. Suresh, E. Nehru, D. Pamanna, D. Venkatesh, M. Yugandhar Kumar, A.S. Sahul Hameed, Ch. Srilatha, P. Hari Babu and Neeraja, T. 2018. Effect of Microsporidian Parasite Enterocytozoon hepatopenaei (EHP) on Pond Profitability in Farmed Pacific White Leg Shrimp Litopenaeus vannamei. Int.J.Curr.Microbiol.App.Sci. 7(05): 1625-1638. doi: https://doi.org/10.20546/ijcmas.2018.705.192 